\title{
Emerging role of exosome-derived long non-coding RNAs in tumor microenvironment
}

\author{
Zhenqiang Sun ${ }^{* \dagger} \mathbb{D}$, Shuaixi Yang ${ }^{\dagger}$, Quanbo Zhou, Guixian Wang, Junmin Song, Zhen Li, Zhiyong Zhang, \\ Jizhong Xu, Kunkun Xia, Yuan Chang, Jinbo Liu* and Weitang Yuan ${ }^{*}$
}

\begin{abstract}
Exosomes are extracellular vesicles released by many cell types and have been attributed for their roles in many diseases including cancer. Exosomes secreted by tumor cells and stromal cells are critical mediators of intercellular communication in tumor microenvironments. Long noncoding RNAs (IncRNAs) are selectively sorted into exosomes and can regulate cancer onset and progression in a variety of ways. In this review, we summarize the characteristics of exosomal IncRNAs and their dysregulation in multiple types of cancer. We provide an overview of current research on exosomal IncRNAs in tumor microenvironments, especially the functions of exosomal IncRNAs in regulating tumor biology. A deeper understanding of the role of exosomal IncRNAs in the tumor microenvironment may help provide new diagnostic and prognostic markers for cancer.
\end{abstract}

Keywords: Exosomes, Long non-coding RNA, Tumor microenvironment, Cancer, Biomarker

\section{Background}

Extracellular vesicles (EVs) are small membranous vesicles that are secreted from numerous cell types, including apoptotic bodies, microvesicles, and exosomes [1]. Exosomes are generated inside multivesicular endosomes or multivesicular bodies (MVBs) and are secreted when these compartments fuse with the plasma membrane [2]. Exosomes facilitate intercellular communication by transporting intracellular components such as protein, RNA and DNA [3]. These components of exosomes are functional in the recipient cells and highly variable depending on the origin cells, and cells can produce different exosomes under different physiological and pathological conditions [4]. In 1981, it was reported that exosomes were 40$150 \mathrm{~nm}$ in diameter and could be isolated from various normal and tumor cells [5]. Numerous studies have shown that exosomes are critical mediators of intercellular communication between tumor cells and stromal cells in local and distant microenvironments [6]. The surface molecules

\footnotetext{
*Correspondence: zqsun82@csu.edu.cn; 1999liujb@163.com; yuanweitang@zzu.edu.cn

${ }^{\dagger}$ Equal contributors

Department of Anorectal Surgery, The First Affiliated Hospital of Zhengzhou University, Zhengzhou 450052, Henan, China
}

of exosomes allow them to target recipient cells $[7,8]$. Once attached to a target cell, exosomes induce signaling via receptor-ligand interactions or can be internalized by endocytosis and/or phagocytosis [9]. On the other hand, exosomes even fuse with the membrane of the target cell to deliver their contents into its cytosol. Exosomes can be isolated from diverse biofluids, such as blood [10], urine [11] and saliva [12]. Different techniques have been used to isolate exosomes, such as ultracentrifugation, density gradients, immunoaffinity, and commercial kits [13]. Furthermore, several methods have been applied to identify exosomes, such as electron microscopy, flow cytometry and western blot analysis [14]. Finally, high-throughput sequencing of clinical samples has been performed to analyze the differential expression of exosomal lncRNAs, which may be potential markers for cancer diagnosis.

According to the origin of the exosomes in the tumor microenvironment, exosomes can be divided into tumor cell secretions and stromal cell secretions. Cancer cells aberrantly secrete large amounts of exosomes to reflect the phenotypic state of stromal cells [15]. As tumors progress, the cargo released in exosomes also dynamically changes, thereby promoting cancer progression. Once taken in by recipient cells, tumor-derived exosomes (TEX) contribute

(c) The Author(s). 2018 Open Access This article is distributed under the terms of the Creative Commons Attribution 4.0 International License (http://creativecommons.org/licenses/by/4.0/), which permits unrestricted use, distribution, and 
to the crosstalk between cancer cells and stromal cells in the tumor microenvironment, such as fibroblasts [16], endothelial cells [17], and immune cells [18]. For instance, cancer cells can inhibit effector functions and induce apoptosis of various immune cells by releasing components of the TEX cargo, such as TGF- $\beta$ [19], NKG2D [20], miR-203 [21], FasL [22], and TRAIL [23]. Stromal cells in the tumor microenvironment also utilize exosomes to transfer molecular contents that affect cancer initiation and progression. MiR-21 is delivered by exosomes derived from neighboring stromal cells in the omental tumor microenvironment, conferring the malignant phenotype and chemoresistance in metastatic ovarian cancer cells. In breast cancer, exosomes secreted by mesenchymal stem cells (MSCs) might reprogram tumor behavior by transferring their molecular contents. MiR-16 is enriched in MSC-derived exosomes and is partially responsible for the anti-angiogenic effect by targeting vascular endothelial growth factor (VEGF) [24]. As discussed above, exosomes regulate the tumor microenvironment by modifying the physiological state of the recipient cell [25]. Thus, exosomes are emerging as critical messengers in tumor progression and metastasis.

Long noncoding RNAs (lncRNAs) are operationally defined as transcripts of greater than 200 nucleotides that function without evident protein-coding function. LncRNAs are present in either the nucleus or cytoplasm, and they can interact with DNA, RNA or proteins [26]. Notably, lncRNAs were demonstrated to play important roles in multiple biological processes by directly or indirectly interfering with gene expression in various cancers [27]. For instance, H19 promotes tongue squamous cell carcinoma migration and invasion by targeting miR-let-7 [28]. The long noncoding RNA lnc-EGFR promotes hepatocellular carcinoma immune evasion by stimulating T-regulatory cell differentiation [29].

Interestingly, lncRNAs can also be packaged into exosomes and act as messengers in cell-to-cell communication [30]. Notably, some IncRNAs are enriched in exosomes, while others are barely present, indicating that some lncRNAs are selectively sorted into exosomes. Specific proteins might act as fundamental lncRNAs carriers to control lncRNA sorting into exosomes, though the exact regulatory mechanisms are not yet fully elucidated. Recently, exosome-derived long noncoding RNAs were reported to regulate tumor apoptosis [31], proliferation and migration and to induce angiogenesis [32]. These exosome-derived long noncoding RNAs have potential as diagnostic and prognostic biomarkers of various cancers [33]. The dysregulation of exosomal lncRNAs could affect the tumor microenvironment and regulate critical oncological behaviors [17]. For instance, hypoxic bladder cancer cells remodel the tumor microenvironment to facilitate tumor growth and development by secreting the oncogenic IncRNA-UCA1- enriched exosomes, and exosomal lncRNA-UCA1 in human serum has potential as a diagnostic biomarker for bladder cancer [34]. Thus, IncRNAs have gained increasing attention in exosome research.

In this review, we discuss the basic properties of exosomes and the functional roles of exosomes in cancer. In particular, we summarize the current knowledge regarding the contribution of exosome-associated lncRNAs to tumor microenvironments, such as tumor angiogenesis, tumor metastasis, and tumor drug resistance.

\section{Biogenesis and characteristics of exosomes in cancer}

Extracellular vesicles (EVs) include apoptotic bodies, microvesicles, and exosomes. Exosomes emerged as important players in cell-to-cell communication in normal physiology and pathological conditions [35]. Exosomes are 40-150 nm EVs released by all cell types in the tumor microenvironment (Fig. 1) [36-38]. Exosomes, generated inside multivesicular endosomes or multivesicular bodies (MVBs), are secreted when these compartments fuse with the plasma membrane [39]. Exosomes likely remove excess and/or unnecessary constituents from the cells, functioning like garbage bags [40]. Additionally, exosomes modify the physiological state of the recipient cell via multiple mechanisms $[41,42]$. On the one hand, exosomes directly target recipient cells through their surface molecules, inducing signaling via receptor-ligand interactions [43]. On the other hand, exosomes fuse with the membrane of a target cell, delivering their contents into its cytosol [44]. Exosomes display a particular organization and composition distinct from the parent cell, even though they share common features [45]. Emerging evidence suggests that exosomes in tumor microenvironments participate in facilitating tumorigenesis by regulating tumor angiogenesis, tumor immunity, and tumor metastasis [46].

\section{Exosome-associated long non-coding RNAs in cancer} Exosomes were confirmed to act as bridges for important information exchange between cells, carrying nucleic acids, proteins, and lipids to the recipient cells [47]. LncRNAs was verified to play important roles in cancer progression and metastasis. Interestingly, exosomes carry a broad range of IncRNAs, which are known to modulate gene expression by translational inhibition or by acting as competitive endogenous RNA [48-50]. We highlight the critical effects exerted by exosomal lncRNAs on tumor progression and drug resistance. For example, the exosome-associated lncRNAs Exo1-4 and RMRP are preferentially packaged and transmitted by the action of exosomes, resulting in enhanced recipient cell viability [46]. 


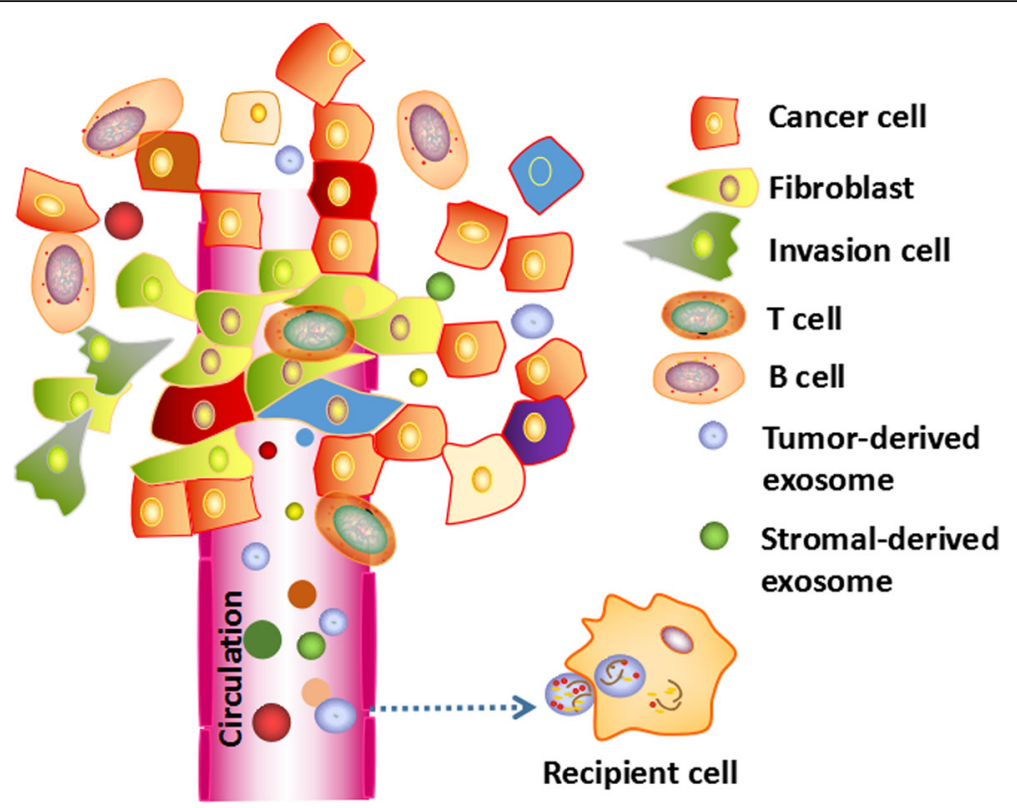

Fig. 1 Exosomes were serected by cancer cells and stromal cells. Exosomes participate in cell-to-cell communications within tumor microenvironment. Circulating exosomes were tranfered to recipient cells, relesaing contents such as mRNAs, noncoding RNAs (miRNAs, IncRNAs and circRNAs), proteins, lipids, and metabolites

\section{Regulation of tumor microenvironment by IncRNAs in exosomes}

Exchange of information in the tumor microenvironment can significantly affect tumor occurrence and development, as well as invasion, metastasis, and other malignant biological behaviors [35]. At the site of the primary tumor, tumor- and stroma-derived exosomes were verified to participate in regulating tumor proliferation and drug resistance [51]. Various mechanisms have been proposed [52]. Exosomes modulate the escape of cancer cells from immune cells by releasing immunoregulatory molecules, such as TGF- $\beta$ [53], FasL [54], and HSP72 [55] (Fig. 2). lncARSR is highly expressed in sunitinib-resistant RCC cells, and cancer cells can disseminate survival skills to other recipient cells via exosomes containing lncARSR [47]. This revealed that exosomal lncRNAs, such as lincUCA1 [31] and lincROR [42], can exert critical functions in the cancer metastatic process (Fig. 2). In addition, tumor-derived exosomes can alter the cellular physiology of distant non-tumor cells to allow dissemination and growth of cancer cells. The influence of exosomal lncRNAs in the tumor microenvironment has recently

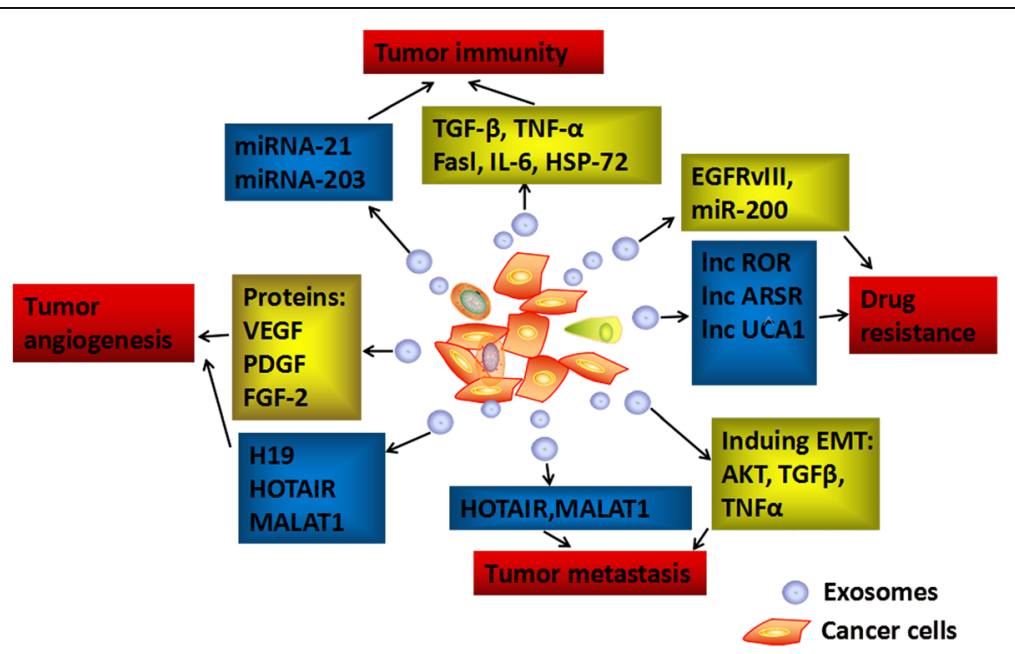

Fig. 2 The functional role of exosomes in tumor microenvironment. Cancer cells and stroma utilize exosomes to modify surrounding cells within tumor microenvironment by transferring ncRNAs and proteins, which induce signaling via receptor-ligand interaction 
been in the limelight $[56,57]$. Exosome-mediated interactions between cancer cells and their surrounding cells within the tumor microenvironment contribute to tumor progression and metastasis (Fig. 2).

\section{Exosomal IncRNA and tumor angiogenesis}

Tumor angiogenesis comprises several steps: enzymatic degradation of the vessel's basement membrane, EC proliferation, migration, sprouting, branching, and tube formation. In the tumor microenvironment, exosomes released by different cell types have been shown to be important mediators during the process of tumor angiogenesis [58-60], such as mesenchymal stem cells, stromal cells, and endothelial cells [61-64]. LncRNAs secreted by tumor-derived exosomes could stimulate the proangiogenic potential of circulating angiogenic cells by increasing their expression of both membrane molecules and soluble factors [65].

For instance, the long non-coding RNA HOTAIR is highly expressed in glioma cells. Interestingly, HOTAIR is packed into exosomes secreted by glioma cells and conveyed to endothelial cells. Then, HOTAIR stimulates angiogenesis by increasing the expression of VEGFA [66], a well-known proangiogenic factor [67]. H19 has been closely associated with hepatocarcinogenesis [68], hepatic metastases [69] and angiogenesis [70]. In $\mathrm{CD} 0^{+}$liver cancer cells, lncRNA H19 is abundant and is packed inside exosomes. Furthermore, exosomal IncRNA $\mathrm{H} 19$ is transferred to and internalized by endothelial cells, promoting an angiogenic phenotype and cell-to-cell adhesion by upregulating VEGF production and release [71]. Similarly, lncRNAs HOTAIR and MALAT1 are upregulated in endothelial-derived exosomes by ethanol, which might have implications for alcohol-induced tumor angiogenesis [72-74].

\section{Exosomal IncRNA and tumor metastasis}

Cancer-derived exosomes have been shown to participate tumor progression. Many groups have confirmed that tumor-derived exosomes are involved in the different steps of the metastatic cascade. Exosomes alter the cellular physiology of both surrounding and distant non-tumor cells to allow dissemination and growth of cancer cells, by triggering vascular permeability or by conditioning pre-metastatic sites in distant organs [75]. Interactions between metastatic cells and their microenvironment via lncRNA-containing exosomes have also been demonstrated. For instance, the lncRNA MALAT-1 is highly expressed in nonsmall-cell lung cancer (NSCLC) patients, and exosomal MALAT-1 is positively associated with TNM stage and lymphatic node metastasis. In lung cancer cell lines, serum exosome-derived lncRNA MALAT-1 promotes tumor migration and prevents tumor cells from apoptosing [76]. Meanwhile, HOTAIR, MALAT1 and MEG3 are significantly differentially expressed in exosomes isolated from cervical cancer patients compared to normal controls [77]. In bladder cancer, HOTAIR is packed into bladder cancer patient urinary exosomes and correlates with cancer progression. Conversely, loss of HOTAIR expression in urothelial bladder cancer cell lines inhibits epithelial-tomesenchymal transition (EMT), which is responsible for tumor metastasis [78]. In colorectal cancer (CRC), exosomal lncRNA $91 \mathrm{H}$ is highly expressed in the serum of CRC patients and usually decreases after operation. Furthermore, IncRNA $91 \mathrm{H}$ was verified to promote tumor migration and invasion by regulating HNRNPK expression [79].

The same phenomenon has been demonstrated in gastric cancer (GC). ZFAS1 is elevated in GC cells, and high expression of ZFAS1 has been correlated with lymphatic metastasis and TNM stage. Interestingly, ZFAS1 is delivered by exosomes, enhancing GC cell proliferation and migration by promoting EMT [80].

\section{Exosomal IncRNA and tumor drug resistance}

Drug therapy is the main means of cancer treatment. However, drug resistance is a thorny problem affecting the effectiveness of treatment. Exosomes, as an important communicator of intercellular communication, participate in drug resistance delivery. Tumor cells and stromal cells in the tumor microenvironment can secrete drug-resistant exosomes, containing proteins and noncoding RNAs. As a research hotspot in recent years, long non-coding RNAs secreted by exosomes play important roles in the transfer of tumor resistance.

Sunitinib resistance is a therapeutic problem for patients with advanced renal cell carcinoma (RCC). LncARSR is highly expressed in sunitinib-resistant RCC cells compared to sunitinib-sensitive RCC cells. LncARSR is packed into exosomes and taken in by recipient cells. Exosomal lncARSR competitively binds miR-34 and miR-449, leading to the increased expression of AXL/c-MET and reactivation of STAT3, AKT, and ERK signaling. Interestingly, activated AKT induces phosphorylation and degradation of FOXO1 or FOXO3a, resulting in the transcriptional derepression of lncARSR, forming a positive-feedback loop [81] (Fig. 3). Additionally, demonstrations of exosome-mediated intercellular pathways provide new insights into hepatocellular carcinoma (HCC) resistance to chemotherapeutic stress [82, 83]. Long noncoding RNAs are enriched within exosomes derived from HCC, such as CAR Intergenic 10, HAR1B, and DISC2 [42]. Linc-VLDLR is reportedly responsible for chemoresistance and is transferred to recipient cells in HCC, though the mechanism is still unclear [84]. TGF $\beta$ can 
reduce the sensitivity of $\mathrm{HCC}$ cells to sorafenib or doxorubicin, and the exosomal lncRNA ROR helps recipient cells acquire chemoresistance in HCC by activating the TGF $\beta$ signal pathway (Fig. 3). In estrogen receptor (ER)positive breast cancer cells, IncRNA UCA1 is loaded in exosomes, resulting in tamoxifen resistance (Fig. 3) [31].

Above all, exosomal lncRNAs may cause acquired chemoresistance within tissues and contribute to a loss of therapeutic effect. The lncRNAs transmitted by exosomes can promote tumor cell adaptation to the tumor environment and the obtainment of survival skills $[85,86]$.

Exosomal IncRNAs and characteristics of tumor stem cells Cancer stem cells (CSCs) are a subpopulation of cancer cells that have the ability to self-renew and give rise to new tumors and metastases. To date, CSCs have been identified in many solid tumors, such as colorectal cancer, renal cancer, and hepatocellular cancers [87]. In addition to the aforementioned promotion of tumor immune escape mediated by exosomes, lncRNAs secreted by exosomes regulate tumor stem cell characteristics [88-90]. Intratumoral hypoxia is one of the most fundamental tumor microenvironment stresses for solid tumors. In the hypoxic microenvironment, tumor cells secrete exosomes containing lncRNAs. Through the regulation of exosomal lncRNAs, the proliferation ability of tumor stem cells is enhanced, thus promoting tumor proliferation and metastasis [34]. In hypoxic bladder cancer cells, hypoxia enhances exosome-mediated shuttling of lncRNAUCA1 into bladder cancer cells. Furthermore, IncRNA-UCA1 promotes tumor growth and progression by inducing EMT [91].

\section{Exosomal IncRNAs as new potential tumor biomarkers}

With the demonstration of the effects of exosomal lncRNAs on tumors, circulating tumor-derived exosomes have emerged as promising biomarkers to monitor cancer progression, such as lncARSR and UAC1 (Fig. 4). Serum exosomal levels of several miRNAs are significantly higher in primary cancer patients compared with healthy controls, such as miR-21 and miR-125b [92, 93]. In addition to miRNAs, IncRNAs associated with tumor-derived exosomes are attractive as potential biomarkers. In colorectal cancer (CRC), MAGEA3 has been reported as a colorectal cancer-related serological biomarker [94]. Additionally, exosomal CRNDE-h levels has been reported to be highly elevated in CRC patients' serum and significantly associated with factors of poor clinical outcome in CRC [95]. Moreover, high CRNDE-p and low miR-217 serum exosomal levels are correlated with advanced clinical stages (III/ IV), tumor classification (T3/T4), and lymph node or distant metastasis [96]. Thus, combined evaluation of serum exosomal CRNDE-p and miR-217 levels shows diagnostic and prognostic potential for CRC patients. In gastric cancer (GC), LINC00152 is likely to be contained in exosomes. Plasma LINC00152 were significantly elevated in gastric cancer patients compared with healthy controls

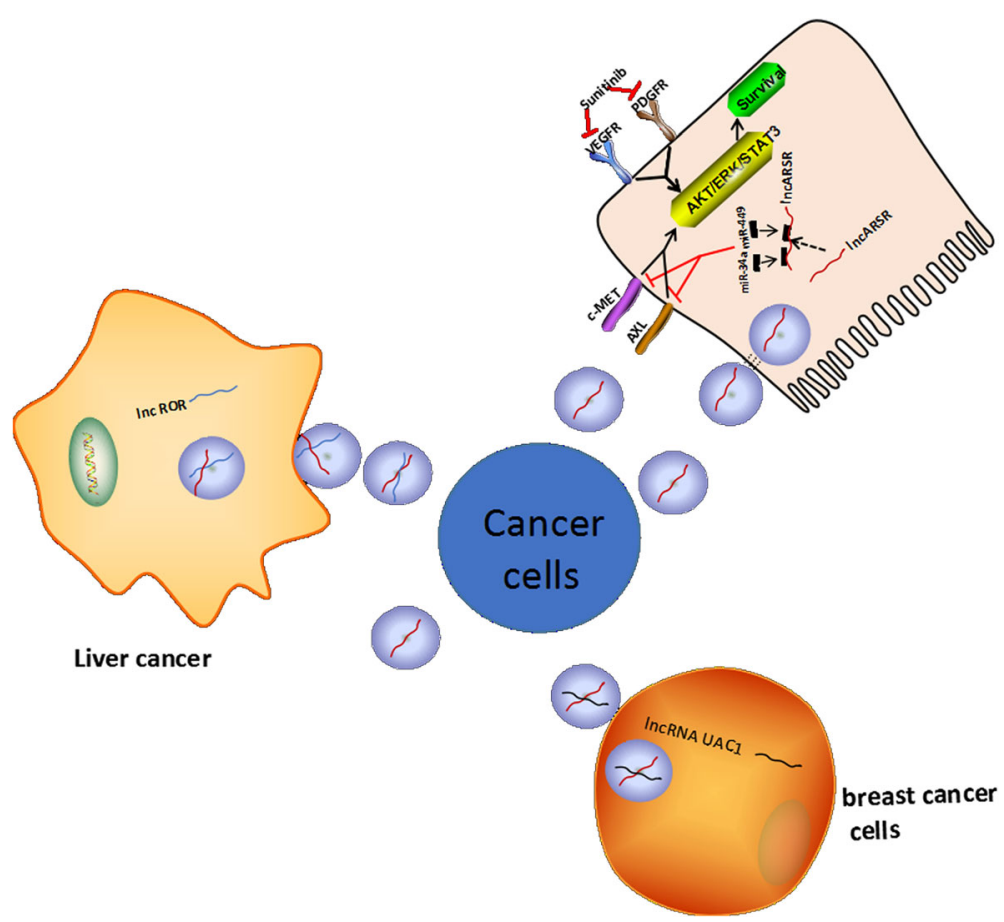

Fig. 3 LnCARSR can be packaged into exosomes and secreted from sunitinib-resistant RCC cells, transferring resistance to recipient-sensitive cells 


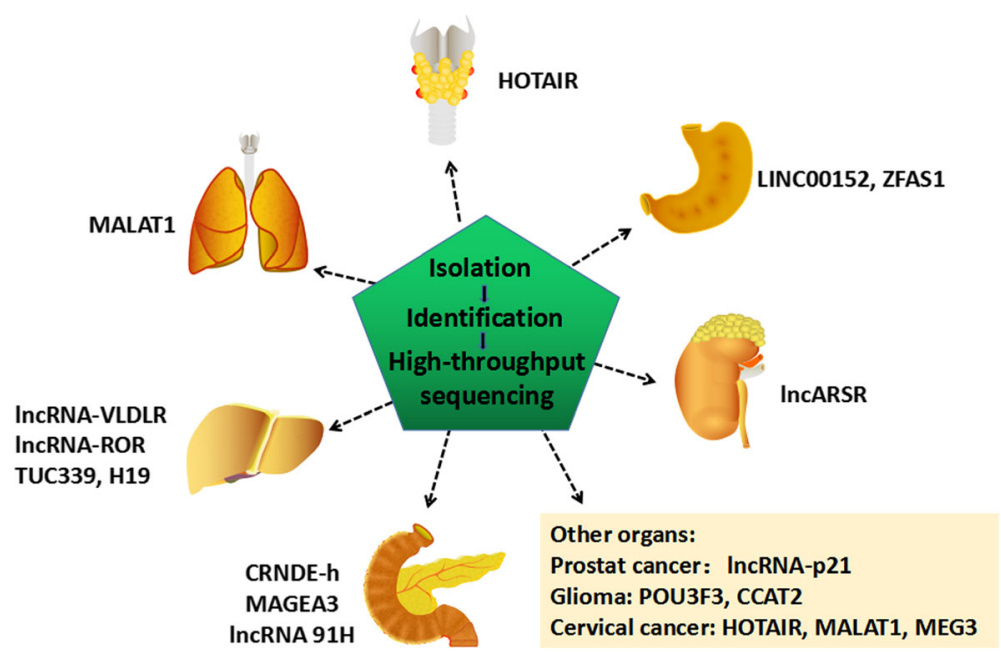

Fig. 4 An increasing number of exosomal IncRNAs have been reported to be aberrantly expressed in human cancers. Exosomal IncRNAs may be potential biomarkers for cancers

[97]. A similar study demonstrated that ZFAS1 was highly expressed in serum exosomes of GC patients, and upregulated ZFAS1 was significantly correlated with lymphatic metastasis and TNM stage. This revealed that exosomal ZFAS1 may serve as a potential diagnostic biomarker for GC [98]. Nonetheless, lncRNAs in exosomes can serve as biomarkers in multiple other cancers, such as lncRNAp21 in prostate cancer and HOTAIR in bladder cancer [99]. As mentioned above, exosomal lncRNAs might have potential as biomarkers for cancer.

\section{Conclusions}

Exosomes are a new means of exchanging information between cells, and play a significant role in tumor microenvironment. The rapid development of exosome research has elucidated novel mechanisms underlying the intrinsic intercellular communication networks during cancer initiation and progression [100, 101]. Tumorderived exosomes promote angiogenesis and coagulation, modulate the immune system, and remodel surrounding parenchymal tissue, which together support tumor progression [102, 103]. Emerging evidence reveals that lncRNAs play significant roles in regulating the tumor microenvironment and tumor progression [104-106]. However, the physiological and pathological roles of exosomes and exosomal lncRNAs in the tumor microenvironment remain to be further explored. Meanwhile, the quantity and heterogeneity of exosomes in body fluids may be a drawback to their use as biomarkers, for these can lead to false negatives or positives in cancer diagnosis. To overcome these obstacles, we need to learn more about these delivery packets and their precise regulatory mechanisms in cancer progression. We believe that an in- depth understanding of exosomes in the tumor microenvironment may contribute to the design of cancer-diagnostic and cancer-prognostic tools. Effective therapeutic strategies for cancer using exosomes as drug carriers are expected in the near future.

Exosomes are detected in the tumor microenvironment, and exosomal lncRNAs play critical roles in facilitating tumorigenesis by regulating angiogenesis, immunity, and metastasis. In the future, circulating exosomal lncRNAs may be used as liquid biopsies and noninvasive biomarkers for the early detection, diagnosis, and treatment of cancer.

\section{Abbreviations}

CRC: Colorectal cancer; CSCs: Cancer stem cells; EMT: Epithelialtomesenchyme transition; EVs: Extracellular vesicles; GC: Gastric cancer; HCC: hepatocellular cancer; LnCRNA: Long noncoding RNA; NCRNAs: Noncoding RNAs; NSCLC: Non-small-cell lung cancer; RCC: Renal cell carcinoma; TEX: Tumor-derived exosomes

\section{Acknowledgements}

This study was supported by the National Natural Science Foundation of China (81560385), the Medical Scientific and Technological Research Project of Henan Province (201702027), Youth Innovation Fund Project of The First Affiliated Hospital of Zhengzhou University (YNQN2017035), and the China Postdoctoral Science Foundation (2017 M610462).

\section{Availability of data and materials} Not applicable.

\section{Authors' contributions}

ZQS, WTY and JBL provided direction and guidance throughout the preparation of this manuscript. ZQS, SXY wrote and edited the manuscript. QBZ, GXW, ZL, JMS and ZYZ reviewed and made significant revisions to the manuscript. JZX, KKX and YC collected and prepared the related papers. All authors read and approved the final manuscript.

Ethics approval and consent to participate Not applicable. 


\section{Consent for publication}

Not applicable.

\section{Competing interests}

The authors declare that they have no competing interests.

\section{Publisher's Note}

Springer Nature remains neutral with regard to jurisdictional claims in published maps and institutional affiliations.

\section{Received: 31 December 2017 Accepted: 3 April 2018} Published online: 20 April 2018

\section{References}

1. Tkach $M$, Théry C. Communication by extracellular vesicles: where we are and where we need to go. Cell. 2016;164:1226-32.

2. Tomasetti M, Lee W, Santarelli L, Neuzil J. Exosome-derived microRNAs in cancer metabolism: possible implications in cancer diagnostics and therapy. Exp Mol Med. 2017;49:e285.

3. Raposo G, Stoorvogel W. Extracellular vesicles: exosomes, microvesicles, and friends. J Cell Biol. 2013;200:373-83.

4. Fujita Y, Yoshioka Y, Ochiya T. Extracellular vesicle transfer of cancer pathogenic components. Cancer Sci. 2016:107(4):385-90.

5. Trams EG, Lauter CJ, Salem N Jr, Heine U. Exfoliation of membrane ectoenzymes in the form of micro-vesicles. Biochim Biophys Acta. 1981; 645:63-70.

6. Teng Y, Ren Y, Hu X, Mu J, Samykutty A, Zhuang X, Deng Z, Kumar A Zhang L, Merchant ML, Yan J, Miller DM, Zhang HG. MVP-mediated exosomal sorting of miR-193a promotes colon cancer progression. Nat Commun. 2017:8:14448.

7. Bobrie A, Krumeich S, Reyal F, Recchi C, Moita LF, Seabra MC, Ostrowski M, Théry C. Rab27a supports exosome-dependent and -independent mechanisms that modify tumor microenvironment and can promote tumor progression. Cancer Res. 2012;72:4920-30.

8. Colombo M, Raposo G, Théry C. Biogenesis, secretion, and intercellular interactions of exosomes and other extracellular vesicles. Annu Rev Cell Dev Biol. 2014;30:255-89.

9. Hoshino A, Costa-Silva B, Shen TL, Rodrigues G, Hashimoto A, et al. Tumour exosome integrins determine organotropic metastasis. Nature. 2015; 527(7578):329-35. https://doi.org/10.1038/nature15756. Epub 2015 Oct 28

10. Caby MP, Lankar D, Vincendeau-Scherrer C, Raposo G, Bonnerot C. Exosomal-like vesicles are present in human blood plasma. Int Immunol. 2005;17:879-87.

11. Bryzgunova OE, Zaripov MM, Skvortsova TE, Lekchnov EA, Grigor'eva AE, Zaporozhchenko IA, Morozkin ES, Ryabchikova El, Yurchenko YB, Voitsitskiy VE, Laktionov PP. Comparative study of extracellular vesicles from the urine of healthy individuals and prostate cancer patients. PLOS One. 2016;11:e0157566.

12. Ogawa Y, Kanai-Azuma M, Akimoto Y, Kawakami H, Yanoshita R. Exosomelike vesicles with dipeptidyl peptidase IV in human saliva. Biol Pharm Bull. 2008;31:1059-62.

13. Ramirez MI, Amorim MG, Gadelha C, Milic I, Welsh JA, Freitas VM, Nawaz M, Akbar N, et al. Technical challenges of working with extracellular vesicles. Nano. 2018;10:881-906

14. Mateescu B, Kowal EJ, van Balkom BW, Bartel S, Bhattacharyya SN, et al. Obstacles and opportunities in the functional analysis of extracellular vesicle RNA - an ISEV position paper. J Extracell Vesicles. 2017;6:1286095.

15. Fatima F, Nawaz M. Stem cell-derived exosomes: roles in stromal remodeling, tumor progression, and cancer immunotherapy. Chin J Cancer. 2015;34(12):541-53. https://doi.org/10.1186/s40880-015-0051-5.

16. Fang T, Lv H, Lv G, Li T, Wang C, Han Q, Yu L, Su B, Guo L, Huang S, Cao D, Tang L, Tang S, Wu M, Yang W, Wang H. Tumor-derived exosomal miR1247-3p induces cancer-associated fibroblast activation to foster lung metastasis of liver cancer. Nat Commun. 2018;9:191.

17. Conigliaro A, Costa V, Lo Dico A, Saieva L, Buccheri S, Dieli F, Manno M, Raccosta S, Mancone C, Tripodi M, De Leo G, Alessandro R. CD90+ liver cancer cells modulate endothelial cell phenotype through the release of exosomescontaining H19 IncRNA. Mol Cancer.2015;14:155.

18. Gao L, Wang L, Dai T, Jin K, Zhang Z, Wang S, Xie F, Fang P, Yang B, Huang $H$, van Dam H, Zhou F, Zhang L. Tumor-derived exosomes antagonize innate antiviral immunity. Nat Immunol. 2018; https://doi.org/10.1038/ s41590-017-0043-5. [Epub ahead of print]

19. Clayton A, Mitchell JP, Court J, Mason MD, Tabi Z. Human tumor-derived exosomes selectively impair lymphocyte responses to interleukin-2. Cancer Res. 2007;67(15):7458-66.

20. Clayton A, Mitchell JP, Court J, Linnane S, Mason MD, Tabi Z. Human tumorderived exosomes down-modulate NKG2D expression. J Immunol (Baltim, Md: 1950). 2008;180(11):7249-58.

21. Zhou M, Chen J, Zhou L, Chen W, Ding G, Cao L. Pancreatic cancer derived exosomes regulate the expression of TLR4 in dendritic cells via miR-203. Cell Immunol. 2014;292(1-2):65-9. https://doi.org/10.1016/j.cellimm.2014.09.004.

22. Whiteside TL. Immune modulation of T-cell and NK (natural killer) cell activities by TEXs (tumour-derived exosomes). Biochem Soc Trans. 2013;41(1):245-51.

23. Huber V, Fais S, lero M, Lugini L, Canese P, Squarcina P, Zaccheddu A, Colone M, Arancia G, Gentile M, Seregni E, Valenti R, Ballabio G, Belli F, Leo E, Parmiani G, Rivoltini L. Human colorectal cancer cells induce T-cell death through release of proapoptotic microvesicles: role in immune escape. Gastroenterology. 2005;128(7):1796-180.

24. Lee JK, Park SR, Jung BK, Jeon YK, Lee YS, Kim MK, Kim YG, Jang JY, Kim CW. Exosomes derived from mesenchymal stem cells suppress angiogenesis by down-regulating VEGF expression in breast cancer cells. PLoS One. 2013;8:e84256.

25. Alexander M, Hu R, Runtsch MC, Kagele DA, Mosbruger TL, Tolmachova T, Seabra MC, Round JL, Ward DM, O'Connell RM. Exosome-delivered microRNAs modulate the inflammatory response to endotoxin. Nat Commun. 2015;6:7321.

26. Rinn JL, Chang HY. Genome regulation by long noncoding RNAs. Annu Rev Biochem. 2012;81:145-66.

27. Gu L, Lu LS, Zhou DL, Liu ZC. UCA1 promotes cell proliferation and invasion of gastric cancer by targeting CREB1 sponging to miR-590-3p. Cancer Med. 2018; https://doi.org/10.1002/cam4.1310. [Epub ahead of print]

28. Kou N, Liu S, Li X, Li W, Zhong W, Gui L, Chai S, Ren X, Na R, Zeng T, Liu H. H19 facilitates tongue squamous cell carcinoma migration and invasion via sponging miR-let-7. Oncol Res. 2018; https://doi.org/10.3727/ 096504018X15202945197589. [Epub ahead of print]

29. Jiang $R$, Tang J, Chen Y, Deng L, Ji J, Xie Y, Wang K, Jia W, Chu WM, Sun B. The long noncoding RNA Inc-EGFR stimulates T-regulatory cells differentiation thus promoting hepatocellular carcinoma immune evasion. Nat Commun. 2017:8:15129. https://doi.org/10.1038/ncomms15129.

30. Valadi H, Ekström K, Bossios A, Sjöstrand M, Lee JJ, Lötvall JO. Exosomemediated transfer of mRNAs and microRNAs is a novel mechanism of genetic exchange between cells. Nat Cell Biol. 2007;9:654-9.

31. Zhang P, Zhou H, Lu K, Lu Y, Wang Y, Feng T. Exosome-mediated delivery of MALAT1 induces cell proliferation in breast cancer. Onco Targets Ther. 2018:11:291-9.

32. Lang HL, Hu GW, Chen Y, Liu Y, Tu W, Lu YM, Wu L, Xu GH. Glioma cells promote angiogenesis through the release of exosomes containing long non-coding RNA POU3F3. Eur Rev Med Pharmacol Sci. 2017;21(5):959-72.

33. Zhao R, Zhang Y, Zhang X, Yang Y, Zheng X, Li X, Liu Y, Zhang Y. Exosomal long noncoding RNA HOTTIP as potential novel diagnostic and prognostic biomarker test for gastric cancer. Mol Cancer. 2018;17(1):68.

34. Xue M, Chen W, Xiang A, Wang R, Chen H, Pan J, Pang H, An H, Wang X, Hou $H$, Li X. Hypoxic exosomes facilitate bladder tumor growth and development through transferring long non-coding RNA-UCA1. Mol Cancer. 2017;16:143.

35. Le MT, Hamar P, Guo C, Basar E, Perdigão-Henriques R, Balaj L, Lieberman J. miR-200-containing extracellular vesicles promote breast cancer cell metastasis. J Clin Invest. 2014;124:5109-28.

36. Kahlert C, Kalluri R. Exosomes in tumor microenvironment influence cancer progression and metastasis. J Mol Med (Berl). 2013:91:431-7.

37. Melo SA, Sugimoto H, O'Connell JT, Kato N, Villanueva A, Vidal A, Qiu L, Vitkin E, Perelman LT, Melo CA, Lucci A, Ivan C, Calin GA, Kalluri R. Cancer exosomes perform cell-independent microRNA biogenesis and promote tumorigenesis. Cancer Cell. 2014;26:707-21.

38. Thery C, Zitvogel L, Amigorena S. Exosomes: composition, biogenesis and function. Nat Rev Immunol. 2002;2:569-79.

39. Webber JP, Spary LK, Sanders AJ, Chowdhury R, Jiang WG, Steadman R, Wymant J, Jones AT, Kynaston H, Mason MD, Tabi Z, Clayton A. Differentiation of tumour-promoting stromal myofibroblasts by cancer exosomes. Oncogene. 2015;34:290-302.

40. Fatima F, Nawaz M. Long distance metabolic regulation through adipose-derived circulating Exosomal miRNAs: a trail for RNA-based 
therapies? Front Physiol. 2017:8:545. https://doi.org/10.3389/fphys.2017. 00545. eCollection 2017

41. Yue S, Mu W, Erb U, Zöller M. The tetraspanins CD151 and Tspan8 are essential exosome components for the crosstalk between cancer initiating cells and their surrounding. Oncotarget. 2015;6:2366-84.

42. Takahashi K, Yan IK, Kogure T, Haga H, Patel T. Extracellular vesicle-mediated transfer of long non-coding RNA ROR modulates chemosensitivity in human hepatocellular cancer. FEBS Open Bio. 2014;4:458-67.

43. Gu J, Qian H, Shen L, Zhang X, Zhu W, Huang L, Yan Y, Mao F, Zhao C, Shi $Y, X u$ W. Gastric cancer exosomes trigger differentiation of umbilical cord derived mesenchymal stem cells to carcinomaassociated fibroblasts through TGF-b/Smad pathway. PLoS One. 2012;7:e52465.

44. Nawaz M, Camussi G, Valadi H, Nazarenko I. The emerging role of extracellular vesicles as biomarkers for urogenital cancers. Nat Rev Urol. 2014;11(12):688701. https://doi.org/10.1038/nrurol.2014.301. Epub 2014 Nov 18

45. Choi DS, Kim DK, Kim YK, Gho YS. Proteomics, transcriptomics and lipidomics of exosomes and ectosomes. Proteomics. 2013;13:1554-71.

46. Hewson C, Capraro D, Burdach J, Whitaker N, Morris KV. Extracellular vesicle associated long non-coding RNAs functionally enhance cell viability. Noncoding RNA Res. 2016;1:3-11.

47. Sansone P, Savini C, Kurelac I, Chang Q, Amato LB, Strillacci A, Stepanova A, Iommarini L, Mastroleo C, Daly L, Galkin A, Thakur BK, Soplop N, Uryu K, Hoshino A, Norton L, Bonafé M, Cricca M, Gasparre G, Lyden D, Bromberg J. Packaging and transfer of mitochondrial DNA via exosomes regulate escape from dormancy in hormonal therapy-resistant breast cancer. Proc Natl Acad Sci U S A. 2017;114(43):E9066-75.

48. Wang $Y H$, Ji J, Wang $B C$, Chen $H$, Yang ZH, Wang $K$, Luo CL, Zhang WW, Wang FB, Zhang XL. Tumor-Derived Exosomal Long Noncoding RNAs as Promising Diagnostic Biomarkers for Prostate Cancer. Cell Physiol Biochem. 2018:46(2):532-545. https://doi.org/10.1159/000488620. [Epub ahead of print].

49. Nawaz M. Extracellular vesicle-mediated transport of non-coding RNAs between stem cells and cancer cells: implications in tumor progression and therapeutic resistance. Stem Cell Investig. 2017;4:83. https://doi.org/10. 21037/sci.2017.10.04. eCollection 2017.

50. Sun ZQ, Chen C, Zhou QB, Liu JB, Yang SX, Li Z, Ou CL, Sun XT, Wang GX, Song JM, Zhang ZY, Yuan WT. Long non-coding RNA LINC00959 predicts colorectal cancer patient prognosis and inhibits tumor progression. Oncotarget. 2017;8:97052-60

51. Fatima F, Nawaz M. Vesiculated long non-coding RNAs: offshore packages deciphering trans-regulation between cells, Cancer progression and resistance to therapies. Non-Coding RNA. 2017;3(1):10. https://doi.org/10. 3390/ncrna3010010.

52. Maia J, Caja S, Strano Moraes MC, Couto N, Costa-Silva B. Exosome-Based Cell-Cell Communication in the Tumor Microenvironment. Front Cell Dev Biol. 2018;6:18

53. Clayton A, Mitchell JP, Court J, Mason MD, Tabi Z. Human tumor-derived exosomes selectively impair lymphocyte responses to interleukin-2. Cancer Res. 2007:67:7458-66.

54. Andreola G, Rivoltini L, Castelli C, Huber V, Perego P, Deho P, Squarcina P, Accornero P, Lozupone F, Lugini L, Stringaro A, Molinari A, Arancia G, Gentile M, Parmiani G, Fais S. Induction of lymphocyte apoptosis by tumor cell secretion of FasL-bearing microvesicles. J Exp Med. 2002;195(10):1303-16.

55. Chalmin F, Ladoire S, Mignot G, Vincent J, Bruchard M, RemyMartin JP, Boireau W, Rouleau A, Simon B, Lanneau D, De Thonel A, Multhoff G, Hamman A, Martin F, Chauffert B, Solary E, Zitvogel L, Garrido C, Ryffel B, Borg C, Apetoh L, Rebe C, Ghiringhelli F. Membrane-associated Hsp72. from tumor-derived exosomes mediates STAT3-dependent immunosuppressive function of mouse and human myeloidderived suppressor cells. J Clin Investig. 2010;120(2):457-71. https://doi.org/10.1172/jci40483.

56. Fan Q, Yang L, Zhang X, Peng X, Wei S, Su D, Zhai Z, Hua X, Li H. The emerging role of exosome-derived non-coding RNAs in cancer biology. Cancer Lett. 2018:414:107-115.

57. Ahadi A, Brennan S, Kennedy PJ, Hutvagner G, Tran N. Long non-coding RNAs harboring miRNA seed regions are enriched in prostate cancer exosomes. Sci Rep. 2016;6:24922.

58. Deregibus MC, Cantaluppi V, Calogero R, Lo lacono M, Tetta C, Biancone L, Bruno S, Bussolati B, Camussi G. Endothelial progenitor cell derived microvesicles activate an angiogenic program in endothelial cells by a horizontal transfer of mRNA. Blood. 2007;110:2440-2448.

59. Gai C, Carpanetto A, Deregibus MC, Camussi G. Extracellular vesiclemediated modulation of angiogenesis. Histol Histopathol. 2016;31:379-91.
60. Hsu YL, Hung JY, Chang WA, Lin YS, Pan YC, Tsai PH, Wu CY, Kuo PL. Hypoxic lung cancer-secreted exosomal miR-23a increased angiogenesis and vascular permeability by targeting prolyl hydroxylase and tight junction protein ZO-1. Oncogene. 2017;36:4929-42.

61. Liang X, Zhang L, Wang S, Han Q, Zhao RC. Exosomes secreted by mesenchymal stem cells promote endothelial cell angiogenesis by transferring miR-125a. J Cell Sci. 2016;129:2182-89.

62. Diehl P, Fricke A, Sander L, Stamm J, Bassler N, Htun N, Ziemann M, Helbing T, El-Osta A, Jowett JB, Peter K. Microparticles: major transport vehicles for distinct microRNAs in circulation. Cardiovasc Res. 2012;93:633-44.

63. Banf C, Brioschi M, Wait R, Begum S, Gianazza E, Pirillo A, Mussoni L, Tremoli E. Proteome of endothelial cell-derived procoagulant microparticles. Proteomics. 2005;5:4443-55.

64. Vallabhaneni KC, Penfornis P, Dhule S, Guillonneau F, Adams KV, Mo YY, Xu R, Liu Y, Watabe $K$, Vemuri MC, Pochampally R. Extracellular vesicles from bone marrow mesenchymal stem/stromal cells transport tumor regulatory microRNA, proteins, and metabolites. Oncotarget. 2015;6:4953-67.

65. Todorova D, Simoncini S, Lacroix R, Sabatier F, Dignat-George F. Extracellular vesicles in angiogenesis. Circ Res. 2017:120:1658-73.

66. Nakamura K, Martin KC, Jackson JK, Beppu K, Woo CW, Thiele CJ. Brainderived neurotrophic factor activation of TrkB induces vascular endothelial growth factor expression via hypoxiainducible factor-1alpha in neuroblastoma cells. Cancer Res. 2006;66:4249-55.

67. Ma X, Li Z, Li T, Zhu L, Li Z, Tian N. Long non-coding RNA HOTAIR enhances angiogenesis by induction of VEGFA expression in glioma cells and transmission to endothelial cells via glioma cell derived-extracellular vesicles. Am J Transl Res. 2017;9:5012-21.

68. Matouk IJ, DeGroot N, Mezan S, Ayesh S, Abu-lail R, Hochberg A, Galun E. The H19 non-coding RNA is essential for human tumor growth. PLoS One. 2007:2:e845.

69. Yu FJ, Zheng JJ, Dong PH, Fan XM. Long non-coding RNAs and hepatocellular carcinoma. Mol Clin Oncol. 2015;3(1):13-17.

70. Fellig Y, Ariel I, Ohana P, Schachter P, Sinelnikov I, Birman T, et al. H19 expression in hepatic metastases from a range of human carcinomas. J Clin Pathol. 2005;58(10):1064-8. doi:10.1136/jcp.2004.023648.

71. Conigliaro A, Costa V, Lo Dico A, Saieva L, Buccheri S, Dieli F, Manno M, Raccosta S, Mancone C, Tripodi M, De Leo G, Alessandro R. CD90+ liver cancer cells modulate endothelial cell phenotype through the release of exosomes containing H19 IncRNA. Mol Cancer. 2015;14:155.

72. M.Y. Fong, W. Zhou, L. Liu, A.Y. Alontaga, M. Chandra, J. Ashby, et al. Breast cancer-secreted miR-122 reprograms glucose metabolism in premetastatic niche to promote metastasis. Nat Cell Biol. 2015;17:183-194.

73. Li L, Li C, Wang S, Wang Z, Jiang J, Wang W, Li X, Chen J, Liu K, Li C, Zhu G. Exosomes derived from hypoxic oral squamous cell carcinoma cells deliver miR-21 to normoxic cells to elicit a prometastatic phenotype. Cancer Res. 2016;76:1770-80.

74. Lamichhane TN, Leung CA, Douti LY, Jay SM. Ethanol induces enhanced vascularization bioactivity of endothelial cell-derived extracellular vesicles via regulation of MicroRNAs and long non-coding RNAs. Sci Rep. 2017;7:13794.

75. Peinado H, Aleckovic M, Lavotshkin S, Matei I, Costa-Silva B, Moreno-Bueno G, Hergueta-Redondo M, Williams C, García-Santos G, Ghajar C, et al. Melanoma exosomes educate bone marrow progenitor cells toward a prometastatic phenotype through MET. Nat Med. 2012;18:883-91.

76. Zhang R, Xia Y, Wang Z, Zheng J, Chen Y, Li X, Wang Y, Ming H. Serum long non coding RNA MALAT-1 protected by exosomes is up-regulated and promotes cell proliferation and migration in non-small cell lung cancer. Biochem Biophys Res Commun. 2017:490:406-14.

77. Zhang J, Liu SC, Luo XH, Tao GX, Guan M, Yuan H, Hu DK. Exosomal long noncoding RNAs are differentially expressed in the Cervicovaginal lavage samples of cervical Cancer patients. J Clin Lab Anal. 2016;30:1116-21.

78. Berrondo C, Flax J, Kucherov V, Siebert A, Osinski T, Rosenberg A, Fucile C, Richheimer S, Beckham CJ. Expression of the long non-coding RNA HOTAIR correlates with disease progression in bladder cancer and is contained in bladder cancer patient urinary exosomes. PLoS One. 2016;11:e0147236.

79. Gao T, Liu X, He B, Nie Z, Zhu C, Zhang P, Wang S. Exosomal IncRNA 91H is associated with poor development in colorectal cancer by modifying HNRNPK expression. Cancer Cell Int. 2018;18:11. https://doi.org/10.1186/ s12935-018-0506-2. eCollection 2018

80. Xu W, He L, Li Y, Tan Y, Zhang F, Xu H. Silencing of IncRNA ZFAS1 inhibits malignancies by blocking Wnt/B-catenin signaling in gastric cancer cells. Biosci Biotechnol Biochem. 2018;82(3):456-65. 
81. Qu L, Ding J, Chen C, Wu ZJ, Liu B, Gao Y, et al. Exosome-transmitted IncARSR promotes sunitinib resistance in renal cancer by acting as a competing endogenous RNA. Cancer Cell. 2016;29:653-68.

82. Qu Z, Wu J, Wu J, Luo D, Jiang C, Ding Y. Exosomes derived from HCC cells induce sorafenib resistance in hepatocellular carcinoma both in vivo and in vitro. J Exp Clin Cancer Res. 2016;35:159.

83. You H, Ding W, Rountree CB. Epigenetic regulation of cancer stem cell marker CD133 by transforming growth factor-beta. Hepatology. 2010;51:1635-44.

84. Takahashi K, Yan IK, Wood J, Haga H, and Patel T. Involvement of extracellular vesicle long noncoding RNA (linc-VLDLR) in tumor cell responses to chemotherapy. Mol Cancer Res. 2014;12:1377-87.

85. Gu P, Chen X, Xie R, Han J, Xie W, Wang B, Dong W, Chen C, Yang M, Jiang J, Chen Z, Huang J, Lin T. IncRNA HOXD-AS1 Regulates Proliferation and Chemo-Resistance of Castration-Resistant Prostate Cancer via Recruiting WDR5. Mol Ther. 2017;25(8):1959-73.

86. Richards KE, Zeleniak AE, Fishel ML, Wu J, Littlepage LE, Hill R. Cancerassociated fibroblast exosomes regulate survival and proliferation of pancreatic cancer cells. Oncogene. 2017;36:1770-8.

87. Tirino V, Desiderio V, Paino F, De Rosa A, Papaccio F, La Noce M, Laino L, De Francesco F, Papaccio G. Cancer stem cells in solid tumors: an overview and new approaches for their isolation and characterization. FASEB J. 2013;27:13-24.

88. Xu C, Zhang Y, Wang Q, Xu Z, Jiang J, Gao Y, Gao M, Kang J, Wu M, Xiong J, Ji K, Yuan W, Wang Y, Liu H. Long non-coding RNA GAS5 controls human embryonic stem cell self-renewal by maintainingNODAL signalling. Nat Commun. 2016;7:13287.

89. Grange C, Tapparo M, Collino F, Vitillo L, Damasco C, Deregibus MC, Tetta C, Bussolati B, Camussi G. Microvesicles released from human renal cancer stem cells stimulate angiogenesis and formation of lung premetastatic niche. Cancer Res. 2011;71:5346-56.

90. Wang S, Li X, Zhu R, Han Q, Zhao RC. Lung cancer exosomes initiate global long non-coding RNA changes in mesenchymal stem cells. Int J Oncol. 2016:48:681-9.

91. Cheng N, Cai W, Ren S, Li X, Wang Q, Pan H, Zhao M, Li J, Zhang Y, Zhao C, Chen X, Fei K, Zhou C, Hirsch FR. Long non-coding RNA UCA1 induces nonT790M acquired resistance to EGFR-TKls by activating the AKT/mTOR pathway in EGFR-mutant non-small cell lung cancer. Oncotarget. 2015;6: 23582-93.

92. Liao J, Liu R, Shi YJ, Yin LH, Pu YP. Exosome-shuttling microRNA-21 promotes cell migration and invasion-targeting PDCD4 in esophageal cancer. Int J Oncol. 2016:48:2567-79.

93. Alegre E, Sanmamed MF, Rodriguez C, Carranza O, Martín-Algarra S, González A. Study of circulating microRNA-125b levels in serum exosomes in advanced melanoma. Arch Pathol Lab Med. 2014;138:828-32.

94. Shantha Kumara HM, Grieco MJ, Caballero OL, Su T, Ahmed A, Ritter E, Gnjatic S, Cekic V, Old L, Simpson AJ, Cordon-cardo C, Whelan RL. MAGEA3 is highly expressed in a subset of colorectal cancer patients. Cancer Immun. 2012;12:16.

95. Liu T, Zhang X, Gao S, Jing F, Yang Y, Du L, Zheng G, Li P, Li C, Wang C. Exosomal long noncoding RNA CRNDE-h as a novel serum-based biomarker for diagnosis and prognosis of colorectal cancer. Oncotarget. 2016;7:85551-63.

96. Yu B, Du Q, Li H, Liu HY, Ye X, Zhu B, Zhai Q, Li XX. Diagnostic potential of serum exosomal colorectal neoplasia differentially expressed long noncoding RNA (CRNDE-p) and microRNA-217 expression in colorectal carcinoma. Oncotarget. 2017:8:83745-53.

97. Li Q, Shao Y, Zhang X, Zheng T, Miao M, Qin L, Wang B, Ye G, Xiao B, Guo J. Plasma long noncoding RNA protected by exosomes as a potential stable biomarker for gastric cancer. Tumour Biol. 2015;36:2007-12.

98. Pan L, Liang W, Fu M, Huang ZH, Li X, Zhang W, Zhang P, Qian H, Jiang PC, Xu WR, Zhang X. Exosomes-mediated transfer of long noncoding RNA ZFAS1 promotes gastric cancer progression. J Cancer Res Clin Oncol. 2017;143:991-1004.

99. Işın M, Uysaler E, Özgür E, Köseoğlu H, Şanlı Ö, Yücel ÖB, Gezer U, Dalay N. Exosomal IncRNA-p21 levels may help to distinguish prostate cancer from benign disease. Front Genet. 2015;6:168.

100. Zhang H, Wang Y, Bai M, Wang J, Zhu K, Liu R, Ge S, Li J, Ning T, Deng T, Fan Q, Li H, Sun W, Ying G, Ba Y. Exosomes serve as nanoparticles to suppress tumor growth and angiogenesis in gastric cancer by delivering hepatocyte growth factor siRNA. Cancer Sci. 2018;109(3):629-41.

101. Ciardiello C, Cavallini L, Spinelli C, Yang J, Reis-Sobreiro M, de Candia P, Minciacchi VR, Di Vizio D. Focus on extracellular vesicles: new frontiers of cell-to-cell communication in cancer. Int J Mol Sci. 2016;17:175.
102. Peinado H, Lavotshkin S, Lyden D. The secreted factors responsible for premetastatic niche formation: old sayings and new thoughts. Semin Cancer Biol. 2011;21:139-46.

103. Ratajczak J, Wysoczynski M, Hayek F, Janowska-Wieczorek A, Ratajczak MZ. Membrane-derived microvesicles: important and underappreciated mediators of cell-to-cell communication. Leukemia. 2006;20:1487-95.

104. Ling H, Fabbri M, Calin GA. MicroRNAs and other non-coding RNAs as targets for anticancer drug development. Nat Rev Drug Discov. 2013;12:847-65.

105. Zheng Y, Liu L, Shukla GC. A Comprehensive review of web-based noncoding RNA resources for cancer research. Cancer Lett. 2017;407:1-8.

106. Sun Z, Ou C, Ren W, Xie X, Li X, Li G. Downregulation of long non-coding RNA ANRIL suppresses lymphangiogenesis and lymphatic metastasis in colorectal cancer. Oncotarget. 2016;7:47536-55.

\section{Ready to submit your research? Choose BMC and benefit from:}

- fast, convenient online submission

- thorough peer review by experienced researchers in your field

- rapid publication on acceptance

- support for research data, including large and complex data types

- gold Open Access which fosters wider collaboration and increased citations

- maximum visibility for your research: over $100 \mathrm{M}$ website views per year

At BMC, research is always in progress.

Learn more biomedcentral.com/submissions 